\title{
Effect of Competence Factor, Independence and Attitude against Professional Auditor Audit Quality Improve Performance in Inspectorate (Inspectorate Empirical Study in South Sulawesi Province)
}

\author{
Asri Usman ${ }^{1}$, Made Sudarma ${ }^{2}$, Hamid Habbe ${ }^{1}$, Darwis Said ${ }^{1}$ \\ ${ }^{1}$ Hasanuddin University Makassar \\ ${ }^{2}$ Brawidjaya University Malang
}

\begin{abstract}
The aims of this research are to know the positive and significant effect among competence, independence and professional attitude partially and simultaneously to inspectorate work achievement South Sulawesi. This inspectoratecontrol is based on regional government implementation and conducted structurally from regency/city level, province to centre level.

The independent variables in this research are competence, independence and professional attitude for dependent variable is inspectorate work achievement the data in this research is primer data taken from questioner implementation directly to inspectorateapparatus of south Sulawesi. Analysis method that is used to examine hypothesis is double regression linear. This analysis is based on 50 respondents through questioner

This research show simultaneous way are competence, independent and professional attitude influence significantly to inspectorate work achievement of shout Sulawesi and partial way competence variable $(X 1)$, independent (X2), professional attitude (X3), influence positive and significantly to inspectorate work achievement of shout Sulawesi. From this coefficientregression we can know are competence variable $(X 1)$, independent $(X 2)$ and professional attitude (X3), have influence positive and significantly to inspectorate work achievement of shout Sulawesi.
\end{abstract}

Key words: Competence, Independence, Professional attitude and Inspectorate work achievement

\section{Introduction}

Demands the implementation of public sector accountability towards good governance in Indonesia has increased.This demand is reasonable, It is characterized by the demands of the public, government officials would support the creation of a clean and dignified, orderly and regular in performing their duties and functions in accordance with applicable regulations.Demands of the community it arises because there is, namely the practices that improperly conductedby government officials.Deviations that occur among government officials, one of which is caused by the lack of effective implementation of the monitoring carried out by the agency are in the body of the local government itself.

As per the Act (Act) No. 32 of 2004 on regional administration, local governments are given broad discretion in carrying out all administrative matters, including planning, implementation, monitoring, control, and evaluation. As a consequence of the authority of autonomy, local governments have an obligation to improve the care and welfare of the community in a fair, equitable, and sustainable. Such obligations can be met if able to manage the potential of the region, namely the potential of natural resources, human resources, and potential financial resources optimally.

Implementation of reforms in various fields requiring the government torespond to the demands of society, namely the widespread implementation of regional autonomy, real and was responsible, especially in finance.Role as controller and guardian of public interest related to the financial sector is the auditor.In carrying out the role of the auditor is responsible for auditing plan and perform the audit to obtain reasonable assurance whether the financial statements are free from misstatements material with supported by technical competence and audit techniques and other competencies gained through formal and informal education as well as experience in practice audit the auditor should beable to gather and evaluate evidence used to support judgments given.

Supervision is one of the important elements in enhancing theutilization of Administrative tasks in the implementation of public administration and development towards the realization of good governance and authoritative.One of these units performs the audit / inspection of local governmentis local inspectorate.According to (Falah, 2005, in NurFitri, 2010:15) has the task of organizing regional inspectorate general supervision of the activities of local governments and other duties assigned by the head of the region, so that the inspectorate duties equal to the internal auditor.Internal audit is an audit conducted by the examiner units that are part of an organization that is supervised (Mardiasmo, 2002). 
Of government audit is one of the important elements in the enforcement of good governance. However, the practice is often far from the expected.NurFitri (2010:15) explains that there are some weaknesses in the auditof government in Indonesia, including the unavailability of adequate performance indicators as the basis for measuring the performance of government both central and local government and it is experienced by public organizations due to the output generated in the form of services public is not easily measured.In other words, the size of audit quality government still being debated.

Audit quality is every possibility that the auditor during theaudit client's financial statements can be found violations that occur in the client's accounting system and reported in the audited financial statements, wherethe auditors in carrying out their duties guided by generally accepted auditing standards and ethical codes of relevant public accountant.

Of the things that have been pointed out above authors encourage and motivate the authors to conduct further research on audit quality inimproving the performance of South Sulawesi Province Inspectorate needs to be supported by appropriate factors so the author chose the title "Effect of Competence Factor, Independence And Attitude Against Professional Auditor Audit Quality Improve Performance In Inspectorate (Inspectorate Empirical Study in South Sulawesi Province) ".

\section{The purpose of the study}

Based on the above formulation of the problem, this study aims to determine the effect of factors Inspectorate personnel competence, independence of the inspectorate personnel and apparatus Professional attitude and simultaneous partial inspectorate toauditqualityin improving the performance of the Inspectorate of South Sulawesi province.

\section{Definition of Quality Audit}

\section{II. literature Review}

De Angelo (1981) defines audit quality (quality audit) asthe probability that an auditor discovered and reported on the existence of a violation of his client's accounting system. The probability of the discovery of a breach depends on the technical capabilities of the auditors and auditor independence.Some studies such as De Angelo (1981); Goldman \&Barlev (1974); Nichols \& Price (1976) generally assume that auditors with the ability to be able to find a violation, and the key is the auditor must be independent.But no information about the ability of the technique (such as audit experience, education, professionalism, and the structure of the audit firm), capability and independence would be difficult to separate.

\section{Quality Audit of Public Sector}

In the public sector audit technique is tantamount to an audit in the private sector.Perhaps the difference is in the political influence of the country concerned and government policy.Demands the implementation of the audit in the public sector, is the provision of public services in order to economically, efficiently and effectively. And as a logical consequence of the delegation of authority and responsibility in the use of funds, both from the central government or local governments themselves. In order for the implementation of the management of public funds is transparent with regard mandated value for money, which ensure public money is managed economically, efficient, effective, transparent, accountable and oriented to the public interest, it would require an examination (audit) by an independent auditor.

\section{Understanding Performance}

Performance is the result of work achieved by an employee in carrying out their duties and responsibilities.Based on the decision of the administrative agency of the Republic of Indonesia Number 239/IX/6/8/2003, performance is an overview of the extent to which the success / failure of the implementation of the duties and functions of an entity.Performance of government agencies is an overview ofthe level of achievement of the objectives or goals of government agencies identified success and failure rate of implementation ofprograms and activities in accordance with the policies that have been set (LAN, 2003)

The term is often associated with the term performance achievements.Term performance or achievements of an interpreter of the English word is 'performance'. According Nelson (1997) performance is the behavior or performance of an organization is directly related to the work activity, the achievement of dutieswhere the term comes from thinking task activities required bythe definition by worker.Few performance according to the following experts

Bambang Kusriyanto in AA Anwar King Mangkunegara (2005:9) "is a performance comparison of the results achieved with the participation of labor per unit of time (usually per hour)." Meanwhile, according to the AA Faustino Gomes Cardosa King Mangkunegara Anwar, (2005: 9 ) "The definition of performance as an expression such as output, efficiency and effectiveness are often associated with productivity." And, according to the AA Anwar King Mangkunegara (2005: 9) itself that the performance is "employee performance 
(performance) is the result of the quality and quantity of work achieved by an employee in carrying out their duties in accordance with the responsibilities assigned to him. Therefore it can be concluded that the performance is the achievement of human resources work, or the work (output) both the quality and quantity of human resources is achieved per unit period of time in carrying out his duties in accordance with the responsibilities assigned to him.

Based on the opinion of several experts, we can conclude that theperformance appraisal (performance) is a systematic assessment to determine employee work outcomes and organizational performance. Besides that, also to determine the appropriate job training, providing a better response in the future and as a basis for determining policy in terms of promotion and reward determination. As well as the performance of the work accomplished by individuals that are tailored to the individual's role or duties in an organization in a given period, which is associated with a certain standard size or value of the organization in which the individual works.

\section{Apparatus competence Inspectorate}

Competence is the knowledge and skills necessary to complete the tasks assigned to individuals (IAI, 2001).Competence or ability possessed by the inspectorate apparatus can be obtained from using these services on their anyone who has important knowledge, skills and experience in conducting internal inspection services in accordance with international standards for the professional practice of internal audit and continuously improve their skills and effectiveness and the quality of their services (The IIA Board Of Directors, 17 June 2000, in AgusMulyono 2009:41). As for the indicators that I use in assessing the competency of working experience and (4) education and training.

\section{The independence of inspectors}

According to (Boynton on Rohman, 2007), the function of the internal auditor iscarrying out an internal examination of the function of which is an independent appraisal function within an organization to examine and evaluate the activities of the organization are carried out.In addition, the internal auditor is also expected to contribute more to the improvement of efficiency and effectiveness in order to improve organizational performance.Thus, the internal auditors of local government play a very important in the creation process of accountability and transparency in the financial management area.

An auditor also should have independence in conducting auditsin order to give opinion or conclusion that it is without any influence from interested parties (BPK, 1998). The second general standard SPKN statement is: "In all matters relating to the work of the examination, the examiner and the examiner organization should be free in the mental attitude and appearance from personal distractions, external, and organizations that may affect independence." So that opinions, conclusions, consideration or recommendation of the results of the examination conducted impartially and perceived impartiality by any party.SPKN details three kinds of disturbance to independence:

\section{Professional Attitude}

According to ArifinLubis (2009), is a professional attitude and the ability of specific expertise in specific areas that have been somebody.Professional attitude is not enough to just "able to work" but also has the ability to "solve the problem" (trouble shooting) field.This allows auditors to quickly and deftly to develop and demonstrate a working knowledge of new and different in relation to theissues, people and work situations.

\section{Previous research}

Alim (2007) study entitled influence on the quality of the competence and independence of the auditor with the auditor ethics as a moderating variable. This study proved that competence has a significant effect on the quality of auditors.Meanwhile, the interaction of competence and ethics of auditors no significant effect on the quality of auditors. This study also found empirical evidencethat the independence of the auditor significant effect on quality.

NurFitri (2010) dalama research entitled Factors Analysis of factors affecting the performance of the district inspectorate PolewaliMandar (empirical studies on PolewaliMandar district inspectorate) as for the results of these studies depends educational level and professional skills, and a significant positive effect on the performance of the inspectorate PolewaliMandar while the adequacy of time positive but not significant effect on the performance of the inspectorate PolewaliMandar, this study also proves that training significantly influence the performance of the inspectorate PolewaliMandar regency.

While Meier and Fuglister (1992) conducted a study on How to improve audit quality and client perception of auditors, the research revealedthat experience in auditing has asignificantimpacton audit quality.The results of the interviews conducted and Fuglister Meier (1992) to the auditor and the client indicates that the client and the auditoragree that training and supervision will improve the quality of auditors. 
Results of research conducted by Samekto, Agus in (Ventura Vol 42001: 77) stated if the actual time given is not enough, then the auditor in carrying out this task with haste according to his ability or perform only those duties.Conversely, if the time limit is too loose, then the auditor will focus less on work that is likely to fail to detect the audit evidence. While the results of research conducted by the Mulyonoagus inDeli Serdang says that background examiner education, technical competence, training and education and certification office training simultaneouslypositive and significant effect on the performance of the inspectorate apparatusDeli Serdang and is partial each significant effect on the performance of the inspectorate Deli Serdang district but who havemostimpactis technical competence.

\section{Conceptual Framework}

Based on several theories and studies conducted by previous researchers, it can be expressed a framework that serves as a guide, as well as the flow of thought and basic research inthe following diagram:

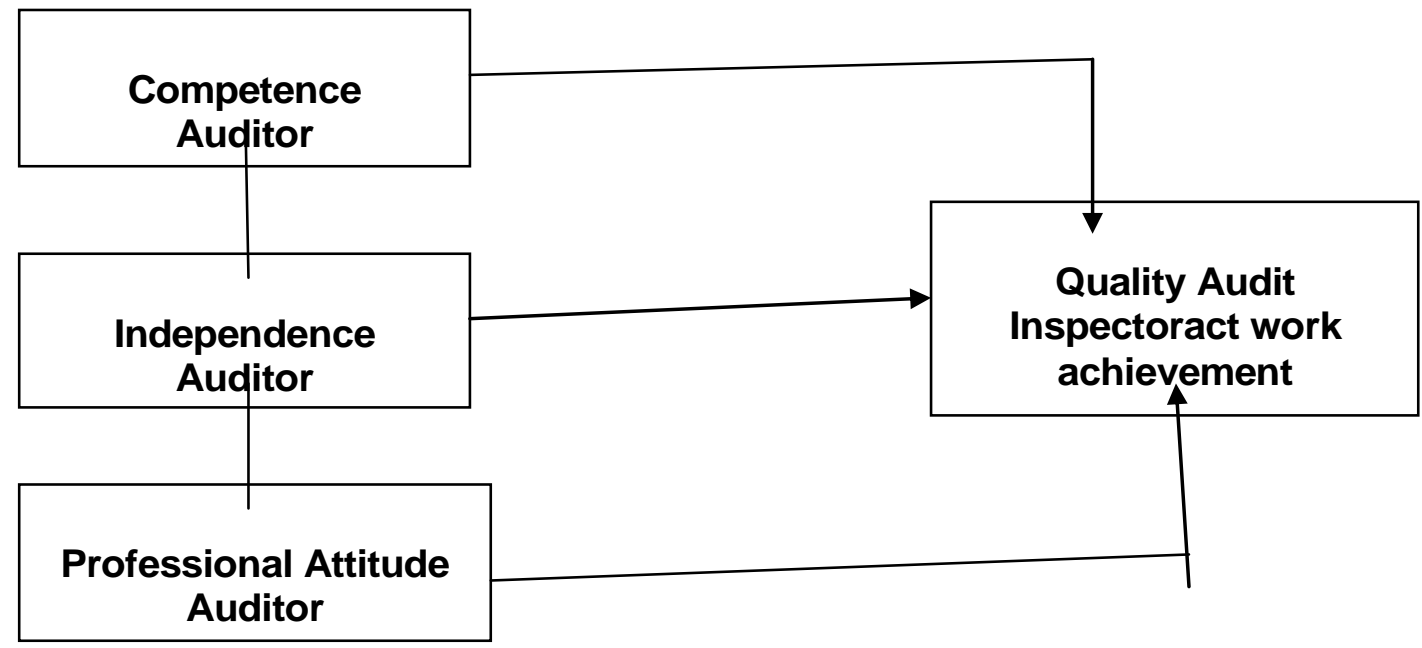

\section{Independent VariablesDependent Variables}

\section{Research Hypothesis}

Based on the description above and the authors point out that the results of previous research results it can be concluded that research hypothesis inthis study are as follows:

1. Partial independence of positive and significant impact on audit quality in improving the inspectorate performance south Sulawesi province

2. Professional attitude is partially positive and significant impact on audit quality in improving the inspectorate performancesouth Sulawesi province

3. Competence partially but not having ansignificantonauditqualityin improving the performance of the inspectorate southern Sulawesi province.

4. Simultaneously competence, Independence and professional attitude has a positive effect on audit quality in improving the performance ofthe inspectorate southern Sulawesi province.

The location and the object of research

\section{Methods}

This study unit of analysis is the organization of the Inspectorate of South Sulawesi province.This isbecause the role of Administrative Inspectorate of South Sulawesi province in carrying out its duties and functions related to all work units(SKPD) in South Sulawesi, namely by carrying out regular supervision or inspection of the Agency, the Agency and the Office of the South Sulawesi provincial government environment based on a program of work annual inspection (PKPT) enacted governor.The success of employee performance greatly affects the performance of the Inspectorate of South Sulawesi which also reflects the success of the South Sulawesi Provincial Government asa whole.

\section{Population and sample}

The population in this study is the auditor's Inspectorate of South Sulawesi province. Methods of selecting samples used in this study by simple random sampling method (simple random sampling) is a member of the sampling technique of randomized population without regard to existing strata in the population.Types of samples in this study are that the sample probability that provide opportunities or equal opportunity for each element or selected members of the population being sampled. 


\section{Methods of data collection}

Data collected through questionnaires (questionnaire) which is a technique of data collection by asking questionnaire filled out by the relevant authorities and the authors make the question refers to each indicator variable.The questionnaire is sent directly to the institution that became the object of research. The number of questionnaires that provided researchers fifty copies, to apparatus Inspectorate South Sulawesi.

\section{Operational definitions of research variables \\ Depending Variable (Dependent variable)}

Depending variable or Dependent Variable (Y) that is used in this research that Audit Quality Audit quality is every possibility that the auditor at the time of audit client's financial statements can be found violations that occur in the system and report accounting the audited financial statements, which in carrying out these duties based on the auditor's auditing standards and ethical codes of relevant public accountant.

\section{Variables (Independent variable)}

Independent Variables or Variable (X) is a variablewhose existence is not affected by other variables, otherwise this variable will affect the other variables.Independent variables or independent variablesused in this study there are three, namely.Apparatus competence Inspectorate $(X 1)$ is a capability that is owned by the South Sulawesi provincial inspectorate aperture, Independence Examiner (X2), Attitude Professional (X3)Examiner assigned to carry out the audit should collectively have the required expertise and certified expertise generally accepted, the better the attitude of an examiner in the field of inspection, the quality of the examination results will be even better.Besides social skills should also be owned by the Provincial Inspectorate, as an examiner socializing is a very important thing, the better an examiner socialize with the object being examined, the level of truth and reliability ofinformation that will get stronger check.

\section{Data Processing Method \\ Model data analysis}

The method of data analysis used in this study ismultiple linear regressionanalysis(Multiple Regression Analysis).

$\mathrm{Y}=\mathrm{A}+\mathrm{B} 1 \mathrm{X} 1+\mathrm{B} 2+\mathrm{B} 2 \mathrm{X} 3 \mathrm{X} 3+\varepsilon$

Where:

$\mathrm{Y}=$ performance score Inspectorate

$\mathrm{a}=$ constant or intercept

$\mathrm{X} 1=$ Competence Administrative Inspectorate

$\mathrm{X} 2=$ Independence Examiner

X3= Professional Attitude

$\mathrm{B} 1 \ldots . . . \mathrm{B} 3=$ Regression coefficients to be calculated

$\varepsilon=$ error factor

\section{Test the hypothesis}

To test the hypothesis is done by looking at the average value of the variables used.To test hypotheses about the influence of factors of competence, independence and professional attitude inspectorate apparatus on audit quality inimproving the performance of the inspectorate Provision South Sulawesi used two forms of hypothesis testing is simultaneous with $F$ test (to see the effect of competence, independence and professional attitude together against quality audit in improving the performance of the inspectorate), and partially by $t$ test (to see the effect of each variable on audit quality in improving the performance of the inspectorate)

\section{Distribution Characteristics of Respondents}

\section{Results}

Description of respondents was representative of the whole population are usedas samples in this study.The samples in this study were within the apparatus province of South Sulawesi are Inspectorate.In this study, researchers distributed questionnaires as many as 50 copies to the authorities within theSouth Sulawesi Provincial Inspectorate.The entire questionnaire distributed 50copies, back 42 and that does not come back as much as eight copies. 
Table 4.1 Data Collection

\begin{tabular}{|l|c|c|}
\hline \multicolumn{1}{|c|}{ Description } & Amount & Percent (\%) \\
\hline Questionnaires were sent numbering 50 copies & $\mathbf{5 0}$ & $\mathbf{1 0 0}$ \\
Questionnaires were not returned & $\mathbf{8}$ & $\mathbf{8 6}$ \\
Questionnaires were returned & $\mathbf{4 2}$ & $\mathbf{8 6}$ \\
$\begin{array}{l}\text { Questionnaire that can be used in } \\
\text { Research }\end{array}$ & $\mathbf{4 2}$ & \\
\hline
\end{tabular}

\section{Description of study variables}

Description of study variables to indicate respondents about the influence factor of Competence, Independence and Professional Attitude apparatus Inspectorate South Sulawesi on audit quality in improving the performance of the Inspectorate of South Sulawesi province. The following arecomments from the respondents dependent and independent variables.

\section{Variable Competence (X 1)}

The indicators that I use in assessing the competency of South Sulawesi Province Inspectorate officials, among others, (1) the level of education, (2) discipline, (3) work experience and (4) education and training. Here respondents to variable competence:

The results of the evaluation questionnaire showed that 42 respondents surveyed giving the answers were varied and if examined, it can be explained that the questionnairerespondents who responded with the most votes in categories agree andstrongly agree, and at least in the category of disagree and strongly disagree.

From the above statement shows that according to the indicators used in assessing the competence of personnel inspectorate turns out that most respondentsagreed categories and provide an assessment of at least provide an assessment on the category of respondents disagreed.Thus, it can be concluded that the respondents generally agree that competence with indicator (1) education, (2) discipline, (3) work experience and (4) education andtraining can improve audit quality and to support performance improvementInspectorate of South Sulawesi province.

\section{Independence of the examiner (X.2)}

The independence examiner is free from interference of personal, external, and organizations that audit quality is also independent and better.Indicators of independence that is free from intervention and support fromthe top leadership; has a neutral stance and not biased; able to avoid a conflict of interest in planning, implementing and reporting on audit results, and do not have a close relationship with the audited.Here respondents to the independence of inspectors. The indicator variable I use in assessing theindependence of thevariablesInspectorate South Sulawesi, among others (1) personal, (2)externally, and (3) Organization.

The results of the evaluation questionnaire showed that 42 respondents surveyed giving the answers were varied and if examined, it can be explained that respondentsrated most highly in the categories agree and disagree, and at least in the category of respondents chose not to agree as much as

From the above statement authors conclude that according to the indicators that I use most of the respondents turned out to pass judgment on agreed categories and at least provide an assessment of the respondentsdid not agree and the category.Thus, it can be concluded that the respondents generally agreed with the examiner when the independence of the indicators that I use that personal interference, external interference and interference can improve the quality of the audit organization can also support the improvement of the performance of the Inspectorate of South Sulawesi province.

\section{Professional attitude (X 3)}

Professional attitude seen of finesse, skill and capacity of theInspectorate of South Sulawesi province.Examiner assigned to carry out the audit should collectively have thenecessaryskillsand expertise have earned certifications general, the more proficient a field examiner in the examination of audit quality, the better so that it can show good performance.Professional attitude will be measured using an indicator variable that is 1).Proficiency and expertise in the field of accounting and auditing, expertise and proficiency in the field of administrative and legal government.As well as 2).The ability to socialize or have skills inrelate to others.

The results of the evaluation questionnaire showed that 42 respondents surveyed in aprofessional manner in line with thevariables of competence and independence of auditorsthat are addressed by the questionnaire respondents with the most votes in the category of total respondents agree and at least in the category of disagree and strongly disagree of total respondents. 
From the above statement shows that according to the indicators usedin this statement most professional respondents agreed rate category and at least pass judgment on category respondents disagree and strongly disagree.Thus, it can be concluded that the respondents generally agree that professional attitude variable with a professional attitude indicator is measured using indicator 1).Proficiency and expertise in the fields of accounting and auditing, expertise and proficiency in the field of administrative and legal government.As well as 2).Social skills or skills in dealing with others can also improve the quality of audits and to support performance improvement Inspectorate South Sulawesi.

\section{Quality audit in improving the performance of the Inspectorate (Y)}

Based on the South Sulawesi Provincial Regulation No. 5 of 2008 on the Establishment of Organization and Work Technical Institute South Sulawesi, Central Administration Inspectorate is a Local Government Implementation Coordination implementGovernment Policy Formulation, Development and Community Services, as well as providingadministrative services to the regional and Governor Regulation No. 40 Year 2009 on translation tasks and functions of the Inspectorate of South Sulawesi Province, where the Inspectorate is supporting elements Governor duty in supervision, and headed by the Inspector under and responsible to the Governor through the Secretary of the Region by the quality audit personnel because inspectorate very support inspectorate performance improvement and creation of good governance

Evaluation of the questionnaire showed that 42 respondents surveyed giving the answers were varied and if examined, it can be explained based onthe questionnaire addressed the respondents with the most votes in categories agree and strongly agree and assessment of the total respondents at least in thecategory of disagree and strongly disagree on the total respondents.

From the above statement indicates that the corresponding indicator turned out to be the most widely used assessment categories of respondents gave at least agree and pass judgment on the category of the respondents strongly disagree.Thus, it can be concluded that the respondents generally agree that the quality of audit in improving the performance of the inspectorate is measured using indicators: inspectorate officials to understand and master the main task; annual inspection work program (PKPKT) achieved annually; examination report (LHP) has run accordance with the existing rules; exposes the results of the examination conducted on time; constantly monitoring results at follow-up; inspectorate officials understand the vision, mission, and goals of the organization; inspectorate officials know the number PKPT every year; inspectorate officers carrying out inspection tasks well; inspectorate officers present at any time when the relevant agencies to conduct examinations; cooperation among employees in performing their duties very well; member of the team that is not sanctioned by the task team leader; inspectorate personnel can work professionally with relevant agencies.

\section{First Hypothesis Testing with $t$ test}

The method in the determination of the terms $t$ table using 5\% significance level with $\mathrm{df}=n k-1$ (in this study $\mathrm{df}=42-4-1=37$ ), in order to get $t$ table value of 2.022691 following table testing the first hypothesis that the effect of variable parcial competency on audit quality in improving the performance of the inspectorate:

The first hypothesis test table with $t$ test

\begin{tabular}{|c|c|c|c|c|}
\hline Variable & t Calculate & t table & Sig. & Decision \\
\hline Competence & 2.746 & 2.022691 & 0.009 & $\begin{array}{c}\text { Hypothesis } \\
\text { proven }\end{array}$ \\
\hline
\end{tabular}

Source: Primary Data Once processed, 2013

From the table above, note $t$ value of variable competence of 2.746 From these values were then compared with the value of $t$ table so as to know the effect of each independent variable on thedependent variable. $t$ value 2.746 competence variables with a significance value of 0.009 while the table shows $2.022691 t$ so it can be concluded that the $t$ table $<t$ count which means partial competence variables have a significant effect on audit quality in improving the performance of the inspectorate.

\section{Second Hypothesis Testing with $t$ test}

To determine the effect of variable partial independenceof the quality of audit in improving the performance of the inspectorate with a confidence level of $95 \%$ or $5 \% \alpha$.If significantly to the quality of audit in improving the performance of the inspectorate then there is the influence of independent variables on the dependent variable, and if not then there is no significant influence of the independent variable on the dependent variable variable.The following table second hypothesis test, namely the effect of variable independence on audit quality in improving the performance of the inspectorate 
The second hypothesis test table

\begin{tabular}{|c|l|c|c|c|}
\hline Variable & tCalculate & t table & Sig. & Decision \\
\hline The independence & 2,085 & 2.022691 & 0,044 & $\begin{array}{c}\text { Hypothesis } \\
\text { proven }\end{array}$ \\
\hline
\end{tabular}

Source: Primary Data Once processed, 2013

From the table above, note $t$ value of variable independence,the valueofwhich is then compared with the value of $t$ table so as to know the effect of each independent variable on thedependent variable. Value of $t$ count variable independence 2.085 with a significance value 0.044 while $t$ table shows 2.022691 so it can be concluded that the $t$ table $<t$ count which means variables significant consequences for the partial independence of the quality of audit in improving the performance of the inspectorate.

\section{Third Hypothesis testing with test $t$}

To determine the effect of variable partial professional attitude towards the quality of audit in improving the performance of the inspectorate with a confidence level of $95 \%$ or $5 \% \alpha$. If significantly to the quality of audit in improving the performance of the inspectorate then there is the influence of the variables are independent of the dependent variable, and if it is not significant then there is the influence of the independent variable on the dependent variable. The following table is a third hypothesis test variables influence the professional attitude towards the quality of audit in improving the performance of the inspectorate:

The third hypothesis test table with t test

\begin{tabular}{|c|l|c|c|c|}
\hline Variable & tCalculate & t table & Sig. & Decision \\
\hline Attitude Professional & 2,115 & 2.022691 & 0,041 & $\begin{array}{c}\text { Hypothesis } \\
\text { proven }\end{array}$ \\
\hline
\end{tabular}

Source: Primary Data Once processed, 2013

From the table above, note the value of $t$ count on the professional attitude variable, the value is then compared with the value of $t$ so that the table canknown effect of each independent variable on the variable dependent. Value of $t$ count variable professional attitude with a significance value 0.0412 .115 while $t$ table shows 2.022691 so it can be concluded that the $t$ table < $t$ count which means professional attitude also partially significant effect on audit quality in improving the performance of the inspectorate.

\section{The fourth hypothesis testing with the F test}

The fourth hypothesis testing is to find simultaneously the influence of independent variables on the dependent variable was analyzed using the F test, that takes into account the significance of the $\mathrm{F}$ value at the output of the calculation with an alpha level of 5\%. If the F-test significance value is less than 5\% then there is the effect of all the independent variables on the variable dependent. F test on the test results of this study can be seen in the table below:

Fourth Hypothesis Test Results Table with Test F

\begin{tabular}{|c|c|c|c|c|c|}
\hline Model & $\begin{array}{l}\text { Sum of } \\
\text { Squares }\end{array}$ & Df & $\begin{array}{l}\text { Mean } \\
\text { Square }\end{array}$ & F & Sig. \\
\hline 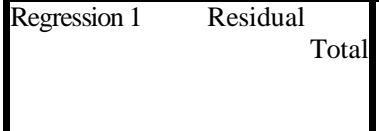 & $\begin{array}{l}443.826 \\
329.317 \\
773.143\end{array}$ & \begin{tabular}{ll|}
3 & \\
3 & \\
& 38 \\
& 41
\end{tabular} & $\begin{array}{r}147.942 \\
8.666\end{array}$ & 17.071 & $.000^{\circ}$ \\
\hline
\end{tabular}

a.

Dependent Variable: y

b. Predictors: (Constant), x3, x2, x1

Source: Primary Data Once processed, 2013

In the regression test results in this study, known $\mathrm{F}$ test value of 17.071 with a significance of 0.000 is smaller than the required significance level of 0.05 . It can be concluded that all the independent variables in this study together (simultaneous) effect on audit quality in improving the performance of the Inspectorate (Y). That means that if competence apparatus inspectorate (X 1 ), independence examiner (X 2 ), and a professional attitude (X 3 ) together will increase the impact on improving the quality of audit and inspectorate support better performance (Y), on the other side if inspectorate personnel competence (X1), independence examiner (X 2 ), and a professional attitude (X 3 ) together will decrease the impact on audit quality and cause loss of 
performance inspectorate $(\mathrm{Y})$

\section{The results of the regression equation}

To facilitate the reading and interpretation of the results of the regression analysis used the equation. Equation or the model contains constants and regression coefficients obtained from the data processing has been done before. Regression equation which has been formulated and then with SPSS for windows made of data processing in order to get the final equation based on research hypothesis is as follows:

1. Regression equation for the variable competence partial effect on audit quality that can support performance improvement inspectorate.

$Y 1=a+B 1 X 1+\varepsilon$

$Y 1=9.936+0.429 \times 1+\varepsilon$

2. Regression equation for variable independence in partial effect on audit quality can improve performance inspectorate.

$Y 2=a+B 2 X 2+\varepsilon$

$Y 2=9.936+0.329 \times 1+\varepsilon$

3. Variable regression equations for the professional attitude arepartial effect on audit quality that can support improvement inspectorate performance.

$Y 3=a+b 3 X 3+\varepsilon$

$Y 3=9.936+0.531 \times 1+\varepsilon$

4. Variable regression equation for the competence, independence and professional attitude simultaneously affect the quality of audits that can support performance improvement inspectorate.

$Y 4=a+B 1 X 1+B 2 X 2+b 3 X 3+\varepsilon$

$Y 4=9.936+0.429 \times 1+0.392 \times 2+0.531 \times 3+\varepsilon$

Statistically fourth regression equation above can be expressed as follows:

a. In this regression model, a constant value of 9.936 listed can be interpreted if the independent variable in the model is assumed to be equal to zero, then the level or magnitude of the performance of the inspectorate will be at 9.936 percent.

b. Magnitude of the regression coefficient B value of 1 for 0.429 in this study can be interpreted that the competence variable (X 1 ) and a significant positive effect on audit quality in improving the performance of the inspectorate (Y). This suggests that when competence has increased by one unit, while the other independent variables are fixed, then the quality of the audit inspectorate also be increased by 0,429 percent to support improved performance audit.

c. Magnitude of the regression coefficient B value 2 of 0.392 in this study can be interpreted that the auditor independence variables (X 2 ) have positive and significant impact on audit quality in improving the performance of the inspectorate (Y).

This suggests that when the independence of the auditor apparatus inspectorateit increased by one unit, while variables other independent fixed, then the quality of the personnel audit inspectorate will also increase by 0.392 percent and encourage better performance so inspectorate.

d. Magnitude of the regression coefficient B value of 3 was 0.531 in this study can be interpreted that the professional attitude variable (X 3 ) have positive and significant impact on audit quality in improving the performance of the inspectorate $(\mathrm{Y})$. This suggests that when a professional attitude inspectorate personnel increased by one unit, while the other independent variables are fixed, then the apparatus audit quality inspectorate will also experience an increase of 0,531 percent and will also improve the performance of the inspectorate.

\section{Analysis of the coefficient of determination $\left(\mathbf{R}^{2}\right)$}

The coefficient of determination can be explained if the dependent variable $\left(\mathrm{R}^{2}\right)>50 \%$. In this study, the coefficient of determination $\left(\mathrm{R}^{2}\right)$ of $0.874(87.4 \%)$. So it can be said that quality of audit in improving the performance of the inspectorate $(\mathrm{Y})$ is able to be explained by the inspectorate personnel competence (X 1 ), auditor independence (X2), and a professional attitude (X 3 ) by $84 \%$ while the remaining $12.6 \%$ is explained by other causes. Likewise, if seen from the value of the adjustedR 2 -value 0.840 (84\%), which means the value of $\mathrm{R}^{2}$ is adjusted for independent variables that exist. Means $84 \%$ of independent variables to explain the dependent variable while the remaining $16 \%$ is explained by other causes. Result of analysis of the coefficient of determination can be seen in the following table: 
The results of the analysis of the coefficient of determination

Table Model Summary

\begin{tabular}{|l|l|r|r|r|}
\hline Model & R & R Square & Adjusted R Square & Std.Error of the Estimate \\
\hline 1 & $.758^{\mathrm{a}}$ & .874 & .840 & 2.94385 \\
\hline
\end{tabular}

a.Predictors: (Constant), x3, x2, x1

Source: Primary Data Once processed, 2013

\section{Discussion of results of hypothesis testing}

In the hypothesis testing based on the results of the calculation can be said that the personnel competence inspectorate (X 1 ), independence examiner (X 2 ), and a professional attitude (X 3 ) significant effect partially or simultaneously on audit quality in improving the performance of the inspectorate (Y). This result can be seen that the better / higher inspectorate personnel competence, independence examiner and professional attitude will certainly produce good quality audit as well and give a good contribution to the improvement of the performance of the inspectorate.

This study is in line with research conducted NurFitri (2010) conducted research on the factors that influence inspectorate performance PolewaliMandar Regency. The results of his research that Partially education level (X1), independence examiner (X 2 ), training (X 3 ), professional skills (X 4 ), work experience (X 5 ), and the adequacy of the time ( $\mathrm{X} 6$ ), respectively significant effect on the performance of the inspectorate, but which have an influence on the performance of the inspectorate is the largest training. and simultaneously keseluruan variables affect the performance of the inspectorate PolewaliMandar.

This study is in line with research Iskandar Rizal Coal (2008) conducted a study on the analysis of the influence of educational background, professional skills, continuing education, and independence of inspectors on the quality of inspection results (empirical studies on the probed field). The results of his research that the educational background, professional skills, continuing education, and independence examiner simultaneously affect the quality of the results of the probed field. Meanwhile, only partially educational background does not influence significantly the quality of the results of the probed field, it is different with the result that researchers get that levels of education have a significant effect on the performance of the inspectorate. Significant effect due to the performance of the duties of the inspectorate is an area of special expertise and owned most of the education inspectorate personnel PolewaliMandar is S1 and S2.

This study is also in line with the results of research conducted by AgusMulyono about competence factor and its influence on the performance of the apparatus inspectorate Deli Serdang says that background examiner education, technical competence, training and education and training certificate simultaneously positive and significant impact on inspectorate apparatus performance Deli Serdang and is partial each significant effect on the performance of the inspectorate Deli Serdang but that has the most impact is the technical competence.

This study is also not in line with the research Alia (2001) entitled the auditor's perception of the quality of the auditor where the results show that experience does not affect the auditor's expertise, so the experience is not also affect the performance of the inspectorate. The difference is caused due Alia research conducted on private companies while researchers conduct research in government agencies.

Meanwhile, this study is also consistent with the results of research conducted by Samekto, Agus in (Ventura Vol 4 2001:77) stated if the actual time given is not enough, then the auditor in carrying out this task with haste according to his ability or just cunduct most of its work. Conversely, if the time limit is too loose, then the auditor will focus less on work that is likely to fail to detect significant audit evidence.

Whereas in my study stated: Partially competence (X 1 ), independence (X 2 ), and a professional attitude (X 3 ), each of which have a significant effect on audit quality inspectorate, it will support performance improvement inspectorate South Sulawesi province and in Simultaneous variable overall significant effect on the performance of South Sulawesi province inspectorate Y. Here's the translation of research of each hypothesis.

\section{Competence influence on audit quality in improving the performance of the inspectorate}

In the results of this study demonstrate the effect of competence on audit quality in improving the performance of the inspectorate is positive and significant. Seen from the positive regression coefficient of 0.429 and significant as seen from the calculation of test $t$ for the first hypothesis was obtained $t$ count $(2.746)>t$ table (2.022691).

Positive influence suggests that inspectorate personnel competence in line with audit quality inspectorate South Sulawesi province, if either the competence or high inspectorate officials will positively influence audit quality inspectorate of good quality or too high so as to improve the performance of the inspectorate, and vice versa if the low inspectorate personnel competence inspectorate audit quality will be low and will decrease the performance of the inspectorate. Influential significantly shows that the competence of 
personnel inspectorate has a very important role in improving the quality of the audit so as to improve the performance of the inspectorate.

Independence influence on audit quality in improving the performance of the inspectorate

In the results of this study demonstrate the effect of the apparatus independence of South Sulawesi provincial inspectorate to audit quality in improving the performance of the inspectorate is positive and significant. Seen from the positive regression coefficient of 0.392 and significant as seen from the calculation of test $t$ for both hypotheses obtained $t$ count $(2,085)>t$ table (2.022691).

Positive influence suggests that the influence of the apparatus independent inspectorate in line with audit quality inspectorate South Sulawesi province, if the independence of the inspectorate officials either high or positive effect on audit quality and can improve the performance of the inspectorate is of good quality or high or commonly called the integrity of the well, and vice versa if the independence of the low inspectorate personnel inspectorate audit quality would be low and may result in decreased performance of the inspectorate. Significant effect suggests that the independence of the inspectorate apparatus also has a very important role in improving audit quality in order to support the performance increasing inspectorate.

\section{Professional attitude influence on audit quality in improving the performance of the inspectorate}

In the results of this study indicate that the influence of the professional attitude apparatus inspectorate to audit quality in improving the performance of the inspectorate is positive and significant. Seen from the positive regression coefficient of 0.531 and a significant level of test calculations are seen $t$ for the third hypothesis obtained $t$ count $(2,115)<t$ table $(2.022691)$.

Positive influence suggests that the influence of the professional attitude apparatus inspectorate in line with audit quality inspectorate South Sulawesi province, if the professional attitude inspectorate personnel either positive or high will affect the quality of the audit so as to make the performance of the inspectorate increased, and vice versa if the independence of the low inspectorate personnel audit quality inspectorate would be low and the performance of the inspectorate will decrease. Significant effect suggests that the independence of the inspectorate apparatus also has a very important role in improving audit quality improves the performance of the inspectorate.

\section{Overall variable influence on audit quality in improving the performance of the Inspectorate}

In the results of this study indicate that the regression test results, known value of $17.071 \mathrm{~F}$ test with a significance of 0.000 is smaller than the significance level of 0.05 is required. Because the F-test significance value is less than 5\% then there is the effect of all the independent variables on the dependent variable. Overall independent variables in this study that the competence, independence and attitude professional together (simultaneous) effect on audit quality in improving the performance of the Inspectorate (Y). That means that if competence apparatus inspectorate (X 1 ), independence examiner (X 2 ), and a professional attitude (X 3 ) together will increase the impact on improving audit quality inspectorate $(\mathrm{Y})$ so as to produce a good performance of the inspectorate, otherwise if inspectorate personnel competence (X 1 ), independence examiner (X 2 ), and a professional attitude (X3 ) together will decrease the impact on audit quality and reduce performance inspectorate $(\mathrm{Y})$

\section{Conclusion}

Based on the analysis of the authors obtain some conclusions based on the hypothesis that proposed, as follows:

\section{The first hypothesis to determine the effect of factors competencearepartial to audit quality in improving the performance of the inspectorate.}

Competence South Sulawesi provincial inspectorate personnel are partialpositive and significant effect on audit quality and to improve the performance of the South Sulawesi provincial inspectorate positive influence suggests that inspectorate personnel competence in line with the quality of the audit to support the improvement of the performance of the South Sulawesi provincial inspectorate, if either inspectorate personnel competence or high will be a positive influence on the quality of audits and can improve the performance of the inspectorate is of good quality as well, and vice versa if low then competenceapparatus inspectorate audit quality inspectorate also be low and can degrade the performance of the inspectorate. Significant effect suggests that inspectorate personnel competence is important towardthe role in improving audit quality inspectorate performance.

\section{The second hypothesis to determine the effect of factors is parcial independence on audit quality in improving the performance of the inspectorate}

The independence of South Sulawesi provincial Inspectorate officials are partial positive and significant impact on audit quality in improving the performance of the South Sulawesi provincial inspectorate, positive effect 
indicates that the effect of the independence of the inspectorate personnel in line with the quality of audit in improving the performance of the South Sulawesi provincial inspectorate, if the independence of the inspectorate officials either or higher will be a positive influence on audit quality so as to improve the performance of good quality inspectorate also commonly referred to as integrity or good, and vice versa if the independence of the low inspectorate personnel inspectorate audit quality would be low and result in reduced performance of the inspectorate. Significant effect suggests that the independence of the inspectorate apparatus also has a very trivial role on audit quality in improving the performance of the inspectorate.

\section{The third hypothesis to determine the influence of the professionalarepartial to audit quality in improving the performance of the inspectorate}

Professional attitude of the South Sulawesi provincial inspectorate personnel are partial positive and significant impact on audit quality in improving the performance of the South Sulawesi provincial inspectorate positive effect indicates that the effect of the professional attitude inspectorate personnel in line with the improved performance of audit quality inspectorate Sulawesi South, if a good professional attitude inspectorate personnel or high positive effect on audit quality inspectorate of good quality so as to improve the performance of the inspectorate, and vice versa if the independence of the low inspectorate personnel inspectorate audit quality would be low and can degrade the performance of the inspectorate. Significant effect suggests that the independence of the inspectorate apparatus also has a very important role on audit quality in improving the performance of the inspectorate.

\section{The fourth hypothesis to determine the factors of competence, independence and attitude professional together simultaneously on audit quality in improving the performance of inspectorate}

Competencies, and Attitudes of Professional Independence of South Sulawesi provincial inspectorate personnel simultaneously together influence positively on the quality of audit in improving the performance of South Sulawesi Province Inspectorate if the competence of personnel inspectorate (X 1 ), independence examiner (X 2 ), and a professional attitude (X 3 ) jointly increase will have an impact on improving the quality of audit inspectorate (Y), and can improve the performance of the inspectorate, as well as the competence of personnel inspectorate otherwise if (X 1 ), independence examiner (X 2 ), and a professional attitude (X 3 ) together will decrease the impact on the quality of the audit inspectorate $(\mathrm{Y})$ and can result in reduced performance of the inspectorate.

\section{Suggestion}

This research is still in need of some repairs to be done in future studies related to the object of study similar to this study in the future, such as by adding some other variables that can be used to analyze the factors that cause the variation minority of respondents who answer the authors obtained answers questionnaire.

The sample of respondents should also be extended to obtain greater representation over the study population studied. This expansion can be geographic scope and range expansion respondents respondent be stakeholders interested in the research that is similar to the object of the study authors.

\section{Limitations of Research}

In conducting this study, the authors faced some limitations of the study. Limited technical knowledge is the most dominant factor in the limitations of this study that led to some fundamental flaws in the study. Deficiencies that include analysis tools

limited, the use of scientific language and some of the shortcomings of his other.

This study also underestimates the characteristics of individuals who were respondents of the study authors. This then leads to the inability of the authors to analyze the causes of answers varied from respondent to certain questions. After going through several processes and compare some of the literature, the characteristics of the individual turns holding role important in establishing the performance of the South Sulawesi provincial inspectorate in order to realize good governance.

This research by the author to represent the entire apparatus of the South Sulawesi provincial inspectorate is the object of study of this research. This occurs because research time is limited so do not allow for the author.

\section{References}

[1]. AgusMulyono 2009. Analisisfakor-faktorkompetensiaparaturinspektoratdanpen garuhnyaterhadapkinerjainspektoratkabupaten deli serdangtesisfakultasekonomiuniversitas Sumatra utara

[2]. Bastian, Indra. 2006. AkuntasiSektorPublik :suatu pen gantar. Jakarta: Erlangga, 2007 . Audit SektorPublik. Edisi 2. Jakarta: SalembaEmpat

[3]. Boynton, William C. 2003. Modern Auditing. William C. Boynton, Raymond N. Johnson, Walter G. Kell; alihbahasa, Paul A. Rajoe, Gina Gania, Lehan Seiyo Busdi; editor, YatiSumiharti. Edisi 7.Jilid 2.Jakarta :Erlangga

[4]. DarlismanDalmy, 2009. Pen garuh SDM, Komitmen, motivasiterhadapkinerja auditor dan reward sebagaivariabee moderating padainspektorat pro vinsijambitesisfakultasekonomiuniversitas Sumatra utara 
[5]. Firdaus, Muhammad. 2004. EkonometrikaSuatuPendekatanAplikatif. Jakarta: BumiAksara
[6]. Fitri, Nur 2010
analisis
factor-faktor
yang

[7]. Halim, Abdul.2007. AkuntansiSektorPublik :AkuntansiKeuangan Daerah. Edisi 3 Jakarta :SalembaEmpat.

[8]. Harun.2009.ReformasiAkuntansidanManajemenSektorPublik di Indonesia.Jakarta :SalembaEmpat

[9]. Ikhsan, ArfandanGhozali,Imam. 2006. MetodologiPenelitianuntukAkuntansidanManajemen.Medan : PT. Madju Medan Cipta

[10]. Joko Widodo,2001 .Good Governance telaahdaridimensiAkuntanbilitas Dan KontrolBirokrasi.

[11]. Mahmudi. 2007. ManajemenKinerjaSektorPublik. Yogyakarta : Unit PenerbitdanPercetakanSekolahTinggiIlmuManajemen YPKN

[12]. Mardiasmo.2002.Akuntansi SektorPublik. Yogyakarta :

[13]. AndiNazir, Moh. 2004. MetodePenelitian. Jakarta: Ghalia Indonesia

[14]. PeraturanMenteri Negara PendayagunaanAparatur Negara nomor PER/05/M.PAN/03/2008, tentangpengukurankualitasaudit

[15]. PeraturanBadanPemeriksaKeuanganRepublik Indonesia Nomor 1 Tahun 2007 tentangStandarPemeriksaanKeuangan

[16]. Peraturan Daerah Provinsi Sulawesi Selatan Nomor 5 Tahun 2008 tentangPembentukanOrganisasidan Tata KerjaLembaga

[17]. PeraturanMenteriDalamNegeriNomor 64 Tahun 2007 tentangfungsiinspektoratprovinsi, kabupaten/kota

[18]. PeraturanMenteriDalamNegeriNomor 13 Tahun 2006 tentangPedomanPengelolaanKeuangan Daerah

[19]. PeraturanMenteriDalamNegeriNomor 44 Tahun 2008 tentangKebijakanPengawasanatasPenyelenggaraanPemerintah Daerah Tahun 2009

[20]. PeraturanPemerintahRepublik Indonesia Nomor 20 Tahun 2001 tentangjenisjenispengawasan

[21]. PeraturanPemerintahRepublik Indonesia Nomor 41 Tahun 2007 tentangOrganisasiPerangkat Daerah

[22]. PrabuMangkunegara, A.A. Anwar 2005. Perandanfungsiinspektoratkabupatengorontalodan pen garuhnyaterhadapkinerja

[23]. Sarwoko. 2005. Dasar-dasarEkonometrika. Yogyakarta: AndiSedarmayanti, 2003.

[24]. Sugyono. 2004. Statistik Non Parametrik. Bandung: Alfabeta

[25]. Ulum, Ihyaul. 2009. Audit SektorPubliksuatu pen gantar. Jakarta: BumiAksara

[26]. Undang-undangNomor 22 Tahun 1999 tentangPemerintahan Daerah Undang-undang (UU) Nomor 32 Tahun 2004 tentangPemerintahandaerah

[27]. Undang-undangNomor 33 Tahun 2004 tentangPerimbanganKeuanganantaraPusatdanDaerah

[28]. Undang-undangNomor 15 Tahun 2004, tentangpemeriksaanUndang-UndangNomor 2 tahun 1998 tentangsistempendidikannasional 